\author{
Ю.М. Мостовой, Л.В. Распутіна, Д.В. Діденко
}

\title{
ПРИХИЛЬНІСТЬ ДО ПОДВІЙНОЇ АНТИТРОМБОЦИТАРНОЇ ТЕРАПІЇ ПІСЛЯ ПЕРЕНЕСЕНОГО ГОСТРОГО КОРОНАРНОГО СИНДРОМУ: РЕАЛІЇ ТА МОЖЛИВОСТІ НА СУЧАСНОМУ ЕТАПІ
}

Вінницький національний медичний університет імені М.I. Пирогова

Резюме. У роботі вивчено прихильність до подвійної антитромбоцитарної терапії (ПАТ) осіб, після перенесеного гострого коронарного синдрому (ГКС) шляхом телефонного опитування 62 пацієнтів, середнього віку (66,3 $\pm 4,7$ року). Прихильність до ПАТ у пацієнтів 3 інфарктом міокарда та нестабільною стенокардією через 6 місяців лікування становить 64,5\% та зменшується протягом наступних шість місяців на $16,1 \%$. Більш прихильними до ПАТ є чоловіки як через шість місяців, так і через рік лікування, причому прихильність жінок через рік зменшилася на $22 \%$, а чоловіків - на 17,4 \%. Найбільш прихильними до ПАТ є пацієнти

Вступ. Згідно з визначенням ВООЗ (2003), прихильність до лікування - це міра, до якої поведінка пацієнта відповідає призначеним медичним рекомендаціям. Під поведінкою пацієнта розуміється прийом медикаментів, дієта та виконання певних призначених змін способу життя [4].

Проблема прихильності до терапії суттєвою мірою стосується пацієнтів із захворюваннями серцево-судинної системи. Зокрема, за даними британських дослідників, серед пацієнтів з артеріальною гіпертензією (АГ) найвищою $є$ прихильність до інгібіторів АПФ та блокаторів рецепторів ангіотензину II - $50 \%$, антагоністів кальцію - 50 $\%$, $\beta$-адреноблокаторів - $43 \%$, діуретинів - $38 \%$ [3]. За даними К. Chen та співавторів [2004], призначення блокаторів ангіотензину II підтримувало прихильність на рівні 81,9 \% випадків, $\beta$ адреноблокаторів - 76,7 \%, інгібіторів АПФ $74 \%$, діуретиків - 70,9 \%, антагоністів кальцію 79\%. [3]. За результатами тримісячного спостереження за лікуванням пацієнтів 3 артеріальною гіпертензією лікарями загальної практики в Україні (програма «Можливості ефективного контролю артеріального тиску за допомогою вітчизняних ліків» 2009) відомо, що 43,2 \% пацієнтів з АГ характеризуються низькою прихильністю до лікування (приймають менше 50 \% призначених ліків) [3]. Серед них переважають пацієнти старшого віку, з наявністю ішемічної хвороби серця (IXC) або таких ускладнень, як інфаркт міокарда, інсульт, серцева недостатність,з підвищеним індексом маси тіла,що мають шкідливі звички, низьку фізичну активність та низький рівень освіти [1].

Існують також дані щодо прихильності до терапії статинами, які є невід'ємною складовою терапії хворих на IXC. Нідерландські дослідники J.P. Dieleman, J.T. van Wyk, M.A. M. van Wijk оцінювали прихильність до лікування статином протягом двох років і проводили цензорування за відміною статину чи переходом на інший препа- після реваскуляризації міокарда, як з інфарктом міокарда, так і з нестабільною стенокардією. Така тенденція відмічається через шість місяців та через 12 місяців лікування. Серед пацієнтів, яким не виконували реваскуляризації, прихильність до ПАТ суттєво зменшувалася протягом року, причому більш суттєво серед пацієнтів 3 IM - на $24 \%$, ніж серед пацієнтів із нестабільною стенокардією - на $16 \%$.

Ключові слова: ішемічна хвороба серця, гострий коронарний синдром, прихильність до терапії, клопідогрель.

рат. Лікування статинами розпочали 3499 пацієнтів, серед них 46 \% - припинили початкове лікування протягом періоду дослідження. Медіана прихильності до лікування становила 55,7 \% [2, 4]. За даними CRUSADE, лише 46\% пацієнтів 3 IXC приймають $\beta$-адреноблокатори, 36 \% - бетаадреноблокатори + ацетилсаліцилову кислоту (АСК) і $21 \%$ - $\beta$-адреноблокатори + АCК + статини [7].

Згідно 3 даними українського реєстру STIMUL через два роки після перенесеного гострого коронарного синдрому (ГКС) відмічається низька прихильність до терапії, незалежно від обраного методу лікування в стаціонарі. До прийому АСК у хворих після реперфузійної терапіі зберігається прихильність - 97,2 \%, але лише третина пацієнтів, яких лікували медикаментозно, вживали АСК. Прийом статинів продовжили лише 22,2 \% пацієнтів після реперфузійної терапії та 9,41 \% після консервативного лікування [2].

Особливе значення після перенесеного ГКС відіграє подвійна антитромбоцитарна терапія (ПАТ) та їі тривалість, що визначено європейськими та вітчизняними рекомендаціями щодо ведення пацієнтів з ГКС з елевацією сегмента ST.

Згідно з рекомендацією Асоціації кардіологів України щодо ведення пацієнтів з ГКС подвійну антитромбоцитарну терапію АСК та пероральним блокатором рецепторів АДФ (АСК та клопідогрель/тикагрелор) рекомендовано продовжувати протягом 12 місяців після ГІМ з елевацією сегмента ST пацієнтам, яким не проводилось стентування (рівень доказовості 1С) [4]. АСК для всіх пацієнтів без протипоказань, підтримуюча доза 75-100 мг на добу, довгостроково незалежно від стратегії лікування (рівень доказовості 1А). Інгібітор рецепторів Р2Y12 (клопідогрель / тикагрелор) протягом 12 місяців рекомендовано призначати пацієнтам із ГКС без елевації ST (рівень доказовості 1С) [8]. 
На переваги комбінації АСК та клопідогрелю перед монотерапією АСК вказує ряд досліджень CURE (2001), CREDO (2002), CHARISMA (2006), CLARITY-TIMI 28 (2005), COMMIT/CCS-2 (2005). Дослідження PARIS (2013) серед пацієнтів після черезшкірних коронарних втручань (ЧКВ) ( $\mathrm{n}=5$ 031) демонструє, що 57,3 \% пацієнтів змінювали прийом ПАТ, що асоціювалося з високим ризиком серцево-судинних подій [6]. Результати дослідження HORIZONS-AMI - встановлено, що ризик тромбозу стента у пацієнтів після первинного ЧКВ iз приводу ГКС з підйомом сегмента ST асоційований із перериванням ПАТ протягом першого місяця лікування.

Враховуючи значну поширеність серцевосудинних захворювань, соціальні та економічні тягарі, що зумовлені зростанням серцевосудинних подій, збільшенням кількості ЧКВ, надзвичайно актуальним $є$ дотримання призначень щодо ПАТ, що може суттєво вплинути на прогноз пацієнтів.

Мета дослідження. Вивчити прихильність до ПАТ пацієнтів після перенесеного ГКС

Матеріл і методи. Дизайн дослідження включав наступні етапи: І. Відбір історій хвороб пацієнтів, що лікувались 3 приводу IM, нестабільної стенокардії або тих, кому виконували стентування коронарних артерій, (n=327); II. Відібрали 175 історій хвороб, в яких пацієнтам рекомендували застосування ПАТ у вигляді АСК та клопідогрелю (Плавіксу) на рік; III. Провели телефонне опитування згідно з розробленим нами опитувальником для оцінки прихильності пацієнтів до ПАТ (табл.1). На наше звернення відгукнулись 62 хворих, середнього віку $(66,3 \pm 4,7)$ років, чоловіків було 45 (72,6 \%), жінок - 17 (27,4 \%).

Всі пацієнти розподіленні на дві групи: 1-ша група - 31 пацієнт, котрим призначали ПАТ шість місяців тому, 2-га група - 31 пацієнт, котрим ПАТ призначали 12 місяців тому. Характеристика обстежених представлена в табл. 2 .

Серед опитаних нами як у 1-й, так і в 2-й групі переважали чоловіки, відповідно: 21
$(67,7 \%)$ та 24 (77,4 \%); переважно це були жителі міста Вінниці, відповідно: 20 (64,5\%) та 22 (71\%); пенсіонери, відповідно: 22 (70,9\%) та 17 (54,8 \%); суттєвих відмінностей між двома групами не виявлено.

Опитані нами пацієнти були розподілені залежно від захворювань (рис. 1). У 1-й групі пацієнтів з ІМ після ургентного стентування було $6(19,3 \%)$, така ж кількість серед опитаних у цій групі були пацієнти з IM, котрим не проводили реваскуляризації, пацієнтів з нестабільною стенокардією після реваскуляризації було 11 (36,5%) та осіб з нестабільною стенокардією без реваскуляризації було 8 (25,8 \%).

У 2-ій групі пацієнтів з IM після ургентного стентування було 10 (32,3\%), серед опитаних осіб з IM, котрим не проводили реваскуляризації, було 11 (35,5 \%), пацієнтів із нестабільною стенокардією після реваскуляризації було 3 (9,7 \%) та осіб з нестабільною стенокардією без реваскуляризації було 7 (22,5\%).

Статистична обробка отриманих результатів виконана на персональному комп'ютері за допомогою пакета статистичних програм SPSS 12.0 для Windows, Grand Pack, Serial Number 9593869) (Бююль А., Цефель П., 2005., Наследов А. Д., 2007). Використовували непараметричні тести (U-тест Манна-Уітні для двох незалежних змінних (вибірок), тест Уілкоксона для порівняння двох залежних змінних (вибірок).

Результати дослідження та їх обговорення. Нами встановлено, що через шість місяців лікування в 1-й групі прихильними до ПАТ були 20 пацієнтів (64,5\%): 15 чоловіків $(71,4 \%)$ та 5 жінок (у $50 \%$ ). Через рік лікування в 2-й групі прихильними до ПАТ залишалися 15 осіб $(48,4 \%)$, причому 13 чоловіків (54\%) та 2 жінки (28\%) (рис. 2). У 1-й групі опитаних 100\% прихильними до ПАТ були пацієнти з IM після реваскуляризації міокарда (8 пацієнтів), 73 \% (8 пацієнтів) пацієнти 3 нестабільною стенокардією після реваскуляризації, та однаково по 33 \% - пацієнти 3 нестабільною стенокардією та IM (по два пацієн-

Таблиця 1

\section{Питання оригінального опитувальника, що застосовували для телефонного опитування}

\footnotetext{
1.Чи призначали Вам після стачіонарного лікування Клопідогрель (Плавікс)?

2.Чи знасте, на який термін призначався цей препарат?

3. Чи продовжуєте приймати на даний момент ией препарат?

4. Чи замінювали Клопідогрель (Плавікс) на інший препарат?

5. Якщо так,то на який саме?

6. Хто рекомендував Вам заміну?

7. Чи зверталися Ви після виписки із стаціонару до сімейного лікаря?

8. Чи зверталися до кардіолога (планово, позапланово)?

9. Чи викликали ШМД після виписки зі стаціонару?

10. Чи лікувались у стаціонарі повторно після виписки?

11. Чи визначали Ви після стаціонарного лікування рівень холестерину?

12. Чи знаєте свій рівень холестерину при останньому вимірюванні?

13. Чи знаєте нормальний показник рівня холестерину?

14. Чи приймаєте гіполіпідемічний препарат?

15. Чи знаєте Ви свою вагу тіла? Чи контролюєте іï?

16. Чи дотримуєтесь дієти? Чи були Вам надані рекомендації щьоо харчування?

17. Ви курите? Якщо так,то чи намагалися Ви покинути курити?
} 
Характеристика обстежених пацієнтів залежно від терміну застосування подвійної антитромбоцитарної терапії

\begin{tabular}{|c|c|c|}
\hline Характеристика & I група $(\mathrm{n}=31)$ & II група $(\mathrm{n}=31)$ \\
\hline Чоловіки, абс., \% & $21(67,7 \%)$ & $24(77,4 \%)$ \\
Середній вік,роки & $59 \pm 4,8$ & $61,4 \pm 2,8$ \\
\hline Жінки, абс., \% & $10(32,3 \%)$ & $7(22,6 \%)$ \\
Середній вік, роки & $73 \pm 6,8$ & $66,7 \pm 4,2$ \\
\hline Жителі міста & $20(64,5 \%)$ & $22(71 \%)$ \\
\hline Жителі області & $11(35,5 \%)$ & $9(29 \%)$ \\
\hline Пенсіонери & $22(70,9 \%)$ & $17(54,8 \%)$ \\
\hline Працюючі пацієнти & $9(29,1 \%)$ & $14(45,2 \%)$ \\
\hline
\end{tabular}

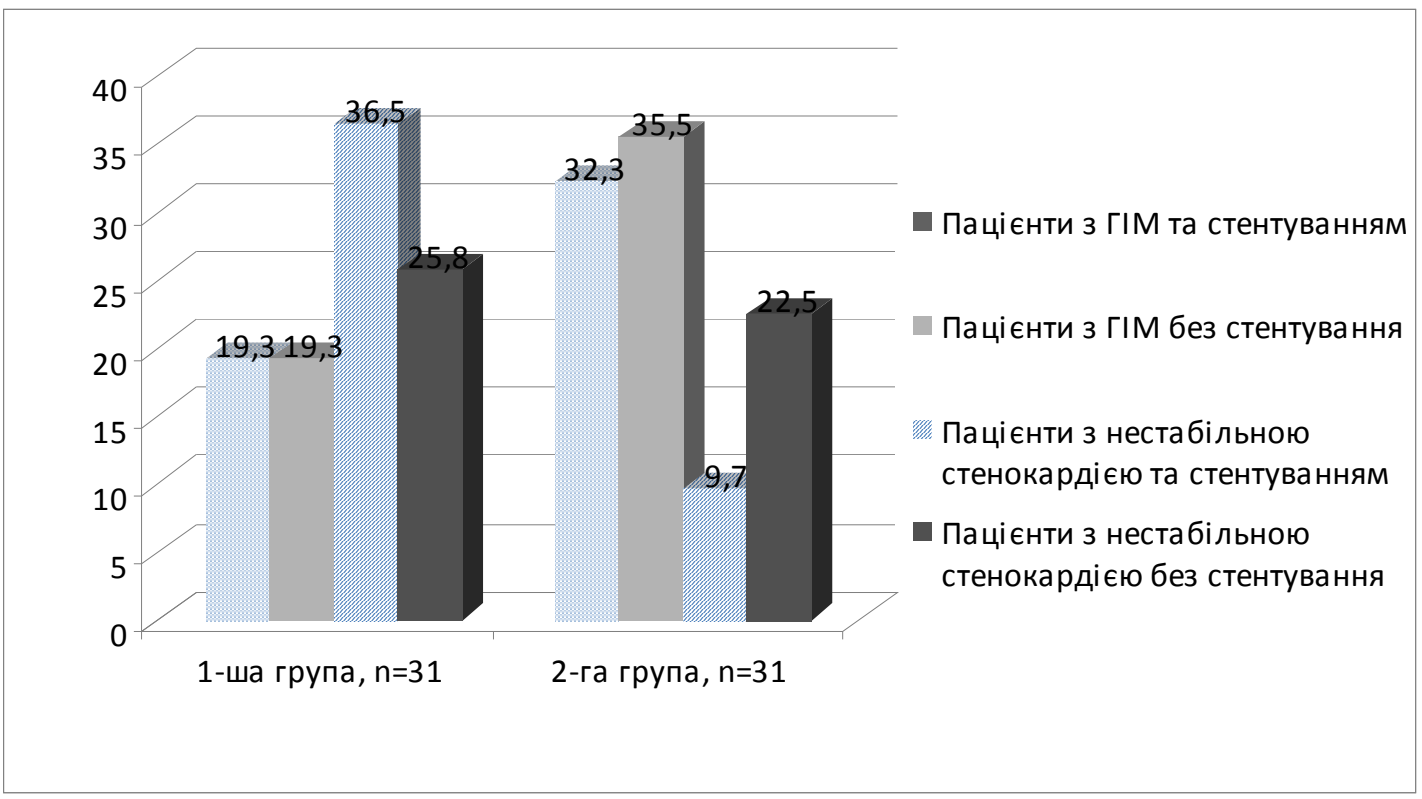

Рис. 1. Розподіл опитаних пацієнтів залежно від причини призначення подвійної антитромбоцитарної терапії

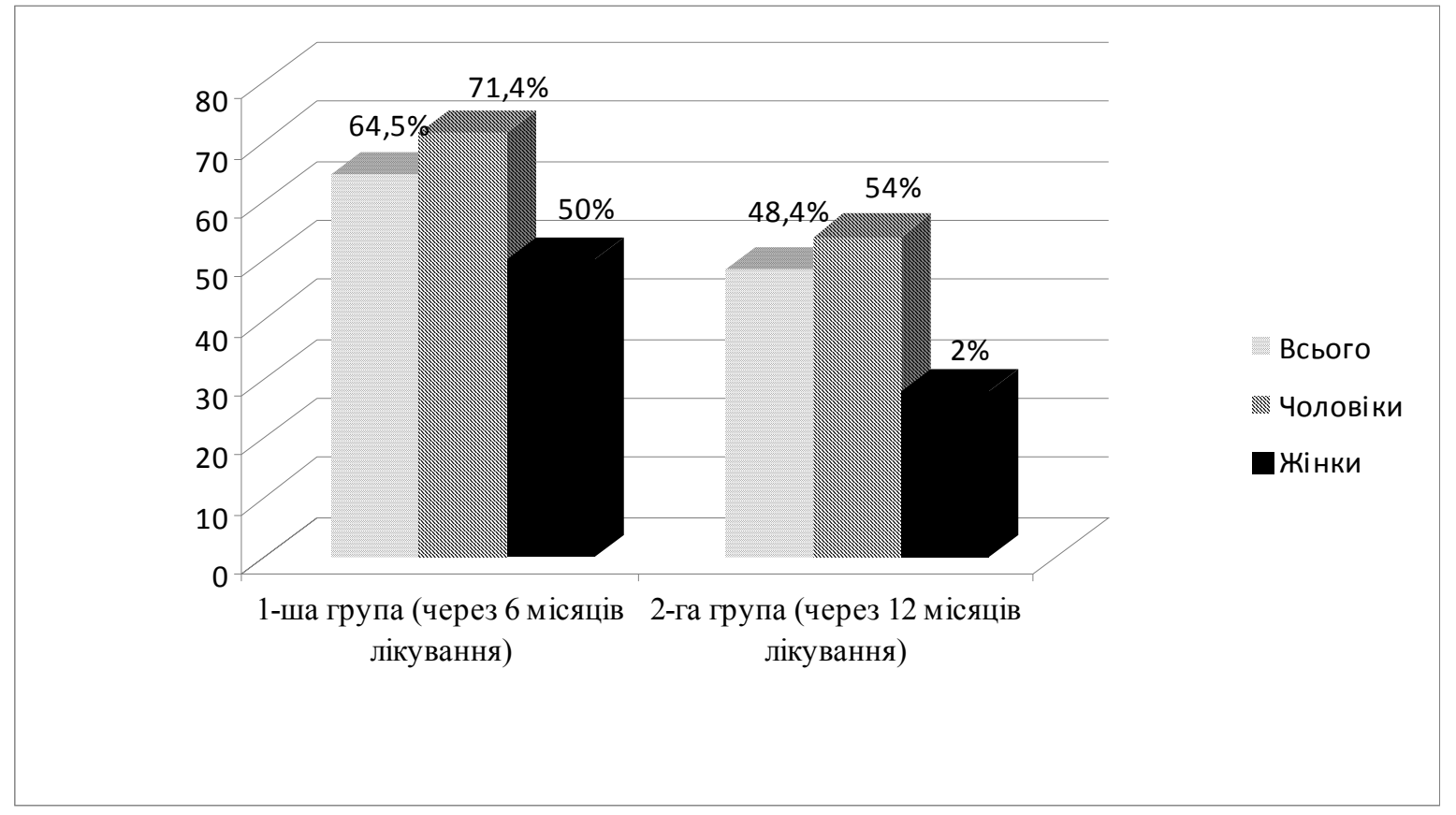

Рис. 2. Прихильність до подвійної антитромбоцитарної терапії через шість та 12 місяців від початку лікування 
Таблиця 3

Прихильність до подвійної антитромбоцитарної терапії

\begin{tabular}{|c|c|c|}
\hline Запитання опитувальника & $\begin{array}{c}\text { Пацієнти, що були при- } \\
\text { хильними до ПАТ, n=40 }\end{array}$ & $\begin{array}{c}\text { Пацієнти, що не були } \\
\text { прильними до ПАТ, } \\
\mathrm{n}=22\end{array}$ \\
\hline $\begin{array}{c}\text { Чи зверталися Ви до свого сімейного лікаря після виписки з } \\
\text { стаціонару? }\end{array}$ & $18(45 \%)$ & $4(18,3 \%)$ \\
\hline $\begin{array}{c}\text { Чи зверталися Ви до кардіолога після виписки зі стаціона- } \\
\text { ру? }\end{array}$ & $34(87 \%)^{*}$ & $14(63,3 \%)$ \\
\hline Чи викликали Ви ШМД після виписки зі стаціонару? & $14(35,5 \%)$ & $14(63,3 \%)$ \\
\hline Чи були у Вас повторні госпіталізації після виписки? & $14(35,5 \%)$ & $10(45,4 \%)$ \\
\hline Чи визначали Ви свій рівень холестерину після виписки зі \\
стаціонару?
\end{tabular}

Примітка. * - різниця $\epsilon$ достовірною при р $<0,05$

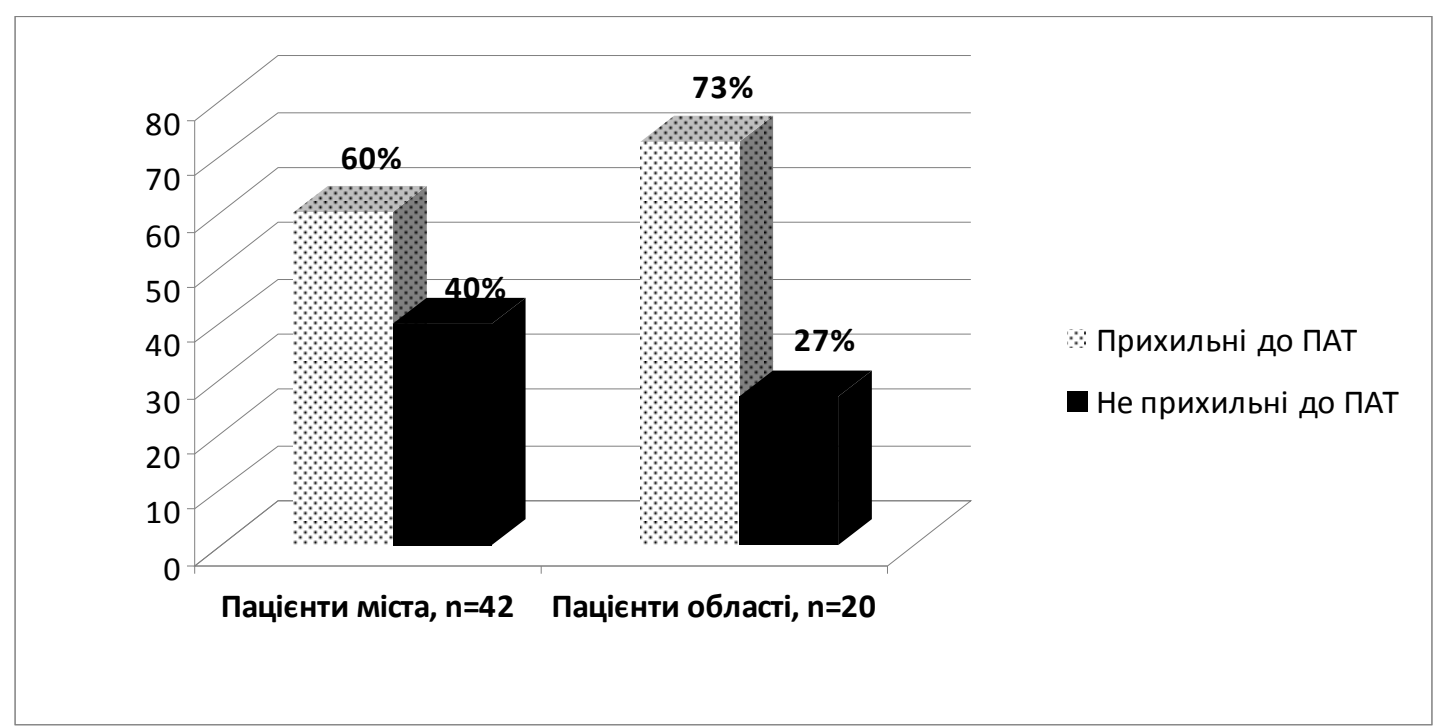

Рис. 3. Розподіл пацієнтів залежно від прихильності до подвійно антитромбоцитарної терапії серед жителів міста та області

ти) без реваскуляризації міокарда. У 2-й групі прихильними до ПАТ були $90 \%$ (девять осіб) 3 IM після реваскуляризації, 67 \% (два пацієнти) із нестабільною стенокардією після реваскуляризаціiі, 43 \% (три пацієнти) із нестабільною стенокардією без реваскуляризації міокарда та 9 \% (один пацієнт) з ІМ без стентування.

Серед всіх опитаних нами пацієнтів 39 (64,5 \%) знали про необхідність прийому ПАТ, термін іï призначення та ризики, що пов'язані з відміною терапії. Серед пацієнтів, хто в процесі лікування протягом шести місяців змінили оригінальний клопідогрель на генеричний препарат, причому три (60 \%) пацієнти керувалися рекомендаціями свого сімейного лікаря, два (40 \%) - прислухалися до думки інших. Зазначене свідчить про ключову роль у прихильності пацієнтів до терапії саме лікарів, тому ïx переконання та позиція можуть суттєво вплинути на рішення хворого щодо продовження ПАТ.
У подальшому ми проаналізували відповіді на запитання залежно від прихильності до рекомендованої подвійної антитромбоцитарної терапії. Всього 40 пацієнтів (64,2 \%) не змінювали ПАТ, що була рекомендована на госпітальному етапі, 22 особи $(35,8$ \%) - змінювали склад ПАТ, насамперед за рахунок заміни оригінального препарату клопідогрелю та генеричні (табл. 3). Встановлено, що пацієнти, які прихильні до ПАТ, достовірно частіше зверталися до кардіолога, на відміну від осіб, що були не прихильними до ПАТ, відповідно: $34(87 \%)$ та $4(18,3 \%)(\mathrm{p}=0,05)$. Пацієнти, що не були прихильними до ПАТ, достовірно частіше викликали швидку допомогу після виписки зі стаціонару, а саме: 14 (63,3 \%) та 14 (35,5\%); частіше були повторно госпіталізовані за цей період, зокрема $14(63,3 \%)$ та $14(35,5 \%)$.

Водночас нами встановлено, що пацієнти, які були прихильними до ПАТ, порівняно з пацієнта- 
ми, що не прихильні до ПАТ, достовірно частіше визначали свій рівень холестерину: 28 (71 \%) та 10 (45,4 \%) відповідно ( $\mathrm{p}=0,002)$; знали нормальний рівень холестерину - 30 (74,2\%) та 12 (55\%) $(\mathrm{p}=0,05)$; частіше отримували гіполіпідемічні засоби - $24(61,3 \%)$ та $8(36,3 \%)(\mathrm{p}=0,05)$; дотримувалися рекомендованої дієти - 26 (64,5 \%) та 8 $(36,3 \%)$; контролювали свою вагу тіла - 34 (87\%) та $4(18,3 \%)(p=0,05)$. Таким чином, група пацієнтів, що $є$ прихильними до ПАТ, більш уважно відносяться до стану свого здоров'я, рекомендацій щодо модифікації способу життя.

Цікавим на нашу думку є той факт, що серед жителів міста прихильними до ПАТ були 25 осіб (60\%), не прихильними до ПАТ - 17 пацієнтів (40\%), тоді як серед жителів області, прихильними до ПАТ були 14 осіб (73 \%) та не прихильними до ПАТ - сім пацієнтів (27 \%) (рис. 3).

\section{Висновки}

1. Таким чином, проведений нами аналіз дозволяє оцінити реальну ситуацію щодо подвійної антитромбоцитарної терапії пацієнтам високого серцево-судинного ризику, а саме після перенесеного гострого коронарного синдрому. Отримані нами дані дозволяють кардіологам, сімейним лікарям, організаторам охорони здоров'я виділяти контингенти хворих для активного роз'яснення щодо ефективності подвійної антитромбоцитарної терапії.

2. Прихильність до подвійної антитромбоцитарної терапії у пацієнтів 3 інфарктом міокарда та нестабільною стенокардією через шість місяців лікування становить 64,5 \% та зменшується протягом наступних шести місяців на 16,1%. Більш прихильними до подвійної антитромбоцитарної терапії є чоловіки як через шість місяців, так і через рік лікування, причому прихильність жінок через рік зменшилася на $22 \%$, а чоловіків на $17,4 \%$.

3. Найбільш прихильними до подвійної антитромбоцитарної терапії є пацієнти після реваскуляризації міокарда, як з інфарктом міокарда, так і нестабільною стенокардією. Така тенденція відмічається як через шість місяців, так і через 12 місяців лікування. Серед пацієнтів, котрим не виконували реваскуляризації, прихильність до подвійної антитромбоцитарної терапії суттєво зменшувалася протягом року, причому більш суттєво навіть серед осіб з IM на $24 \%$, ніж серед хворих на нестабільну стенокардію - на $16 \%$. $60 \%$ осіб у вирішенні питання щодо подвійної антитромбоцитарної терапії прислухається до думки свого лікаря.

4. Пацієнти, що були прихильними до подвійної антитромбоцитарної терапії, достовірно частіше визначали свій рівень холестерину, приймали гіполіпідемічні засоби, контролювали вагу тіла, дотримувалися дієти. Більш прихильними до подвійної антитромбоцитарної терапії були жителі Вінницької області, ніж міста Вінниці.

Перспективи подальших досліджень. Для 3'ясування причин щодо неприхильності або прихильності до лікування безумовно слід вивчити низку важливих параметрів, а саме: рівень освіченості та інтелекту хворих, рівень кваліфікації лікаря, матеріальну спроможність пацієнтів, що буде зроблено в наступних наших дослідженнях.

\section{Література}

1. Беш Д.І. Вплив стентування коронарних артерій на вибір та прихильність до подальшого лікування пацієнтів 3 ішемічною хворобою серця / Д.І. Беш // Укр. мед. часопис. - 2010. - № 5 (79). - С. 4-9.

2. Валуєва С.В. Український реєстр STIMUL: ефективність різних методів лікування гострих коронарних синдромів з елевацією сегмента ST та прихильність хворих до лікування у післяінфарктний період (результати дворічного спостереження) / С.В. Валуєва // Укр. кардіол. ж. - 2013. - № 2. - С. 16-18.

3. Результати тримісячного спостереження за лікуванням пацієнтів 3 артеріальною гіпертензією лікарями загальної практики в Україні (Програма «Можливості ефективного контролю артеріального тиску за допомогою вітчизняних ліків»)/ Ю.М. Сіренко, Г.Д. Радченко, І.М. Марцовенко [та ін.] // Артеріол. гіпертензія. - 2009. - № 4. - С. 12-18.

4. Adverse Effects and Reason for switch reported by patients on antihypertensive therapy / K. Chen, D.Glass, C.Chiou [et al.] // Am. J. Hypertens. - 2004. - Vol. 17. P. 26-29.

5. CHARISMA Investigators. Clopidogrel and aspirin versus aspirin alone for the prevention of atherothrombotic events / D.L. Bhatt, K.A. Fox, W. Hacke [et al.] // N. Engl. J. Med. - 2006. - № 43 (5). - P. 27-30.

6. CLARITY-TIMI 28 Investigators. Addition of clopidogrel to aspirin and fibrinolytic therapy for myocardial infarction with ST-segment elevation / M.S. Sabatine, C.P. Cannon, C.M. Gibson [et al.] // N. Engl. J. Med. 2005. - № 45. - P. 45-48.

7. CREDO Investigators. Clopidogrel for the Reduction of Events During Observation. Early and sustained dual oral antiplatelet therapy following percutaneous coronary intervention: a randomized controlled trial / S.R. Steinhubl, P.B. Berger, J.T. Mann [et al.] // JAMA. - 2002. № 53 (6). - P. 18-23.

8. Role of Clopidogrel in Managing Atherothrombotic Cardiovascular Disease / S. Eshaghian, S. Kaul, S. Amin [et al.] // Annals of Internal Medicine. - 2007. - № 146 (6). P. 434-441.

\section{ПРИВЕРЖЕННОСТЬ К ДВОЙНОЙ АНТИТРОМБОЦИТАРНОЙ ТЕРАПИИ ПОСЛЕ ПЕРЕНЕСЕННОГО ОСТРОГО КОРОНАРНОГО СИНДРОМА: РЕАЛИИ И ВОЗМОЖНОСТИ НА СОВРЕМЕННОМ ЭТАПЕ}

\section{Ю.М. Мостовой, Л.В. Распутина, Д.В. Диденко}

Резюме. В работе изучено приверженность к двойной антитромбоцитарной терапии (ДАТ) после перенесенного острого коронарного синдрома путем телефонного опроса 62 пациентов, среднего возраста $(66,3 \pm 4,71)$ лет. Приверженность к ДАТ у пациентов с инфарктом миокарда (ИМ) и нестабильной стенокардией через шесть мес. лечения составляет 64,5 \% и уменьшается на протяжении следующих шести месяцев на $16,1 \%$. Более привержен- 
ными к ДАТ были мужчины как через 6 мес., так и через год лечения, причем приверженность женщин через год уменьшилась на 22 \%, а мужчин на - 17,4 \%. Наиболее привержены к ДАТ пациенты после реваскуляризации миокарда как с ИМ, так и с нестабильной стенокардией. Такая тенденция отмечается через шесть месяцев и через 12 месяцев лечения. Среди пациентов, которым не проводилась реваскуляризация, приверженность к ДАТ существенно уменьшалась на протяжении года, причем больше среди больных ИМ - на 24 \%, чем среди пациентов с нестабильной стенокардией - на $16 \%$.

Ключевые слова: ишемическая болезнь сердца, приверженность к лечению, клопидогрель.

\section{ADHERENCE TO DOUBLE ANTITHROMBOCYTIC THERAPY (DAT) AFTER ACUTE CORONARY SYNDROME EXPERIENCE (ACS): MODERN REALITIES AND POSSIBILITIES}

\section{Y.M. Mostovoy, L.V. Rasputina, D.V. Didenko}

Abstract. In this work the affection to dual antiplatelet therapy (DAT) of the patients who carried over the acute coronary syndrome was observed by the telephone survey of the middle-aged patients $(66,3 \pm 4,7)$. The number of patients who had experienced myocardial infarction (MI) and unstable angina and remained adherent to DAT was 64,5\% after 6 months of treatment and diminished by $16,1 \%$ during the next 6 months. Men remained more adherent to DAT, both after 6 months and 1 year of treatment, while women's adherence diminished by $22 \%$ after a year. In comparison, men's adherence to DAT decreased only by $17,4 \%$ after a year. The highest adherence to DAT is among the patients who had experienced revascularization of myocardium, from MI as well as unstable angina. Such a tendency is found after 6 months as well as after 12 months of treatment. We should point out that the patients who hadn't experienced revascularization of myocardium stopped the DAT more often. After 12 months their number reduced by $16 \%$ among those who had unstable angina and noticeably by $24 \%$ among the patients with MI.

Key words: coronary artery disease, adherence to therapy, clopidogrel.

M.I. Pyrohov National Medical University (Vinnytsia)

Рецензент - проф. О.І. Волошин

(C) Ю.М. Мостовой, Л.В. Распутіна, Д.В. Дід, 2015
Buk. Med. Herald. - 2015. - Vol. 19, № 4 (76). - P. 120-125

Надійшла до редакції 21.09.2015 року 